UDC: 37.154 .03

DOI: https://doi.org/10.24195/2414-4665-2017-4-30

Tetiana Holubenko,

PhD (Candidate of Pedagogical Sciences), associate professor, Department of Theory and Technology of Social Work,

National Pedagogical Dragomanov University, 9, Pyrohova Str., Kyiv, Ukraine

\title{
FORMATION OF FUTURE SOCIAL WORKERS' READINESS FOR HOME-NURSING WORK WITH ELDERLY PEOPLE: SCIENTIFIC AND PEDAGOGICAL FACTORS
}

The article represents the results of summative and formative assessment of scientific and pedagogical factors of the formation of future social workers' readiness for home-nursing work with elderly people. In order to optimize the educational process a careful search has been made to find such variants of the best scientific and methodical decision making that would most effectively contribute to the formation of future social workers' readiness for home-nursing work with the elderly on the basis of students' mastering the basic social and pedagogical knowledge and skills. In the present study scientific and pedagogical factors of the formation of future social workers' readiness for home-nursing work with elderly people are represented by a combination of four components: motivational-value, cognitive-orientative, content-professional and practical-activity. In accordance with them, there have been formulated four criteria for the mentioned structural components: value, informational, competence and activity. There have been described the levels of future social workers' readiness for home-nursing work with the elderly by identifying specific features that characterize the manifestation of their main criteria. The low level of readiness is considered to be the initial one. The medium level (reproductive) characterizes students' emotional and value attitude to the problems of professional self-improvement. The high level (constructive) is characterized by a full realization of students' motivational-value, cognitive-orientative, content-operational and practical-activity readiness for home-nursing work with the elderly. Readiness for home-nursing work with elderly people has been determined as a socio-psychological and professional manifestation of the relationship between professional orientation and other important personality traits (worldview, life attitudes and spiritual values, moral-volitional and emotional spheres), which involves the formation of moral values, intellectual qualities, knowledge, abilities and skills for home-nursing work with elderly people. There have been analyzed real conditions of future social workers' readiness for home-nursing work with the elderly according to three levels of value, informational, competence and activity criteria at the summative and formative stages of the experiment. Analyzing the data of evaluation of future social workers' readiness for home-nursing work with elderly people it has been proved that there are advantages of readiness indicators formation according to four criteria, which consist in person-oriented training, developing a practical orientation in the process of future social workers' readiness formation towards the mentioned professional activity.

Keywords: readiness, readiness formation, diagnostic experiment, formative experiment, home-nursing work, the elderly, future social worker.

\section{Introduction}

An important social problem of the $21^{\text {st }}$ century all over the world and in Ukraine is the creation of comfortable conditions for the elderly in order to help them accept the process of aging. A significant increase in the proportion of the elderly and older population influences all spheres of social life and induces the state education system to determine priority directions of social work with the specified age group.

According to the proportion of population aged 60 and over, Ukraine is one of the top thirty oldest countries, now taking $25-26^{\text {th }}$ place in the world ranking on this indicator. Based on the demographic forecast for Ukraine up to 2050 (revised in 2010), it is determined that the highest growth rates in the elderly population are expected in 2015-2020 and in the first half of the 2040s, and the highest level of aging can be achieved in the 2050s.

A famous Ukrainian scientist O. Bohomolets has defined the process of aging as a natural and inevitably growing biological process that is developing long before the old age and is accompanied by a decrease in the body adaptive capacity and an increase in the death probability [1].

The opinion of a famous Ukrainian gerontologist $\mathrm{V}$. Frolkis [2] deserves a particular attention. He believes that even when considering aging as the most universal phenomenon of nature, there are some paradoxes: everybody easily identifies the difference between a young and an old man, but nobody can give an exhaustive scientific description of the aging essence and mechanisms of its development.

In order to draw attention of the Ukrainian society to the process of population aging and provide harmonization of social relations among representatives of different generations, the issue of future social workers' training for home-nursing work with elderly people becomes of vital importance.

Taking into account modern socio-demographic, socio-economic conditions and high requirements for intellectual, professional and moral-ethical personal development, Ukrainian education system puts the primary tasks that are directly reflected in the system of future social workers' university professional training. 
At the same time, it is possible to optimize the educational process only on the basis of students' mastering the basic social, pedagogical knowledge and skills, that requires a careful search for such variants of the best scientific and methodical decision making that would most effectively contribute to the formation of future social workers' readiness for home-nursing work with the elderly. To achieve this goal, it is necessary to make learning purposeful, to intensify students' motivation for this type of activity, to increase the level of didactic and methodological support, information content of educational subjects, the use of innovative educational technologies, focused on training of future social worker's personality.

O. Karpenko notes that the problems of modern social specialists' professional training, the definition of content and forms have always been relevant. No doubt, their relevance is only increasing over time, as the rapidly changing situation of social development promotes the emergence of new requirements for this category of workers, and, consequently, various aspects of their professional training [3, p. 162].

The issue of specialists' readiness for professional activity has become relevant since the end of $19^{\text {th }}$ - beginning of $20^{\text {th }}$ century. One of the first scientists studying this phenomenon was D. Uznadze [4], who treated readiness as a guideline. In the 1970s the issue of readiness was examined by M. Diachenko [5], V. Slastonin [6] and others. In the 1990s due to the formation and development of social work in Ukraine, this problem was studied by the researchers such as O. Bezpalko [7], A. Kapska [8], O. Karpenko [9], I. Kozubovska [10], L. Mishchyk [11], V. Poltavets [12], T. Semyhina [13], S. Kharchenko [14], and others.

Some aspects of social work with elderly people were illustrated in scientific works of domestic and foreign scholars (O. Bezpalko [7], A. Kapska [8],
T. Kolenichenko [15], Yu. Matskevych [16], O. Topol [17], L. Tiuptia [18], and others).

The aim of the article is to determine and analyze the results of diagnostic and formation experiment of the process of future social workers' readiness for homenursing work with elderly people development.

To achieve the goal, a complex of research methods was used and their effectiveness in the process of future social workers' readiness for home-nursing work with elderly people development was proved.

\section{Discussion}

The experiment took place on the basis of Academy of Labour, Social Relations and Tourism, University College of Social Sciences in Chestochowa, Poland, Bila Tserkva Institute of Economics and Management of High school 'Open International University of Human Development "Ukraine", Zaporizhzhya National University, Lviv Polytechnic National University, National Pedagogical Dragomanov University.

410 students of $1^{\text {st }}-4^{\text {th }}$ courses majoring in social work (education qualification level "bachelor") were involved in the research. The experimental group (EG) included 200 respondents, the control group (CG) -210 and 90 experts ( 60 specialists of social institutions and 30 university lecturers).

In our study scientific and pedagogical factors of the formation of future social workers' readiness for homenursing work with elderly people are represented by a combination of four components: motivational-value, cognitive-orientative, content-professional and practicalactivity. In accordance with them, we have formulated four criteria for the mentioned structural components: value, informational, competence and activity criteria, which are characterized by a set of indicators (Table 1):

Criteria and indicators of students' readiness for home-nursing work with elderly people

\begin{tabular}{|l|l|}
\hline Readiness criteria & \multicolumn{1}{c|}{ Readiness indicators } \\
\hline Value & $\begin{array}{l}\text { 1. Interest in searching for innovative forms of work with elderly people. } \\
\text { 2. Persistence and initiative. } \\
\text { 3. The need to establish communication relations with the elderly. } \\
\text { 4. Striving for cooperation and help. }\end{array}$ \\
\hline Informational & $\begin{array}{l}\text { 1. Knowledge about technologies of social work with the elderly. } \\
\text { 2. Knowledge about mechanisms of interdisciplinary work with elderly people organization. } \\
\text { 3. Knowledge about normative-legal base on home-nursing work with the elderly. } \\
\text { 4. Knowledge about getting social help by elderly people. }\end{array}$ \\
& $\begin{array}{l}\text { 1. Knowledge about content and features of home-nursing work with the elderly. } \\
\text { 2. Knowledge about mechanisms of home-nursing work with elderly people organization. } \\
\text { Activity }\end{array}$ \\
$\begin{array}{l}\text { 4. Knowledge about methods and techniques of home-nursing work with the elderly. } \\
\text { 1. Creative ability and its manifestation in home-nursing work with the elderly. } \\
\text { 2. Ability to master various types of home-nursing work with elderly people (socio-pedagogical, } \\
\text { socio-medical, socio-psychological, socio-economic, socio-legal). } \\
\text { 3. Ability to solve problems in a non-standard situation in the process of home-nursing work } \\
\text { with elderly people. } \\
\text { 4. Ability to master various forms of home-nursing work with the elderly. }\end{array}$
\end{tabular}


We have described the levels of future social workers' readiness for home-nursing work with the elderly by identifying specific features that characterize the manifestation of their main criteria.

The low level of readiness is considered to be the initial one. At this level students do not take a conscious position of a specialist in home-nursing work with the elderly; their educational subject knowledge has an isolated nature, and the ability to do home-nursing work with elderly people is not developed enough.

The medium level (reproductive) characterizes students' emotional and value attitude to the problems of professional self-improvement; students realize the relationship between self-improvement and success in their future profession, although they are not always able to formulate the appropriate goal clearly; they have systematic subject knowledge, but they do not always understand interdisciplinary connections. They know their level of readiness for professional activity, in particular, for homenursing work with the elderly. This level is marked by a sufficient motivational-value readiness for home-nursing work with elderly people, but practical-activity readiness is not implemented enough.

The high level (constructive) is characterized by a full realization of students' motivational-value, cognitiveorientative, content-operational and practical-activity readiness for home-nursing work with the elderly; they have a great interest in the problems of professional selfimprovement; the final self-determination of a student occurs, in particular, according to the implementation of home-nursing work with elderly people. This level also includes students' scientific-research and analyticalgeneralized readiness for home-nursing work with the elderly.

During our diagnostic study the following tasks were solved: there were identified levels of future social workers' readiness for home-nursing work based on the described criteria by using a complex of diagnostic methods: author's questionnaire "Determination of future social workers' motivational-value readiness for home-nursing work with the elderly", "Diagnostics of professional competence level" questionnaire (adapted according to O. Karpenko), "Identification of knowledge and skills level to implement home-nursing work with elderly people" test, "Value orientations" methodology (M. Rokych [19]), "Professional motivation" methodology (A. Krylov).

\section{Discussion}

Readiness for home-nursing work with elderly people has been determined as a socio-psychological and professional manifestation of the relationship between professional orientation and other important personality traits (worldview, life attitudes and spiritual values, moral-volitional and emotional spheres), which involves the formation of moral values, intellectual qualities, knowledge, abilities and skills necessary for homenursing work with the elderly [20, p. 75].
Based on the data mentioned above, we assert that the system of future social workers' training for homenursing work with elderly people should be built taking into account the following features: readiness is a fundamental condition for the successful implementation of home-nursing work with the elderly; readiness allows to modify actions in case of difficulties, that is extremely important for the right decision making in complicated situations; readiness regulates the process of homenursing work; readiness personifies the process of professional training; readiness ensures a positive effect of students' preparedness; professional readiness is a specification of the process of students' self-expression and selfrealization; readiness contributes to professional identification and self-determination in the profession; readiness is an integral indicator of the higher educational establishment work efficiency.

To identify the ways of improving future social workers' professional training for home-nursing work with the elderly, it is necessary to determine readiness indicators applied to a particular professional activity. It will clearly direct the entire process of social workers' training for home-nursing work with elderly people. At the same time specialists' readiness indicators should firstly determine students' readiness for home-nursing work with elderly people, which is constantly changing (ensuring a double lead of the current social order); secondly, the criteria for evaluating future specialists' readiness should reflect the specifics of home-nursing work with elderly people; and thirdly, readiness indicators should represent not only the result of professional training, but also the whole process of specialists' development at various stages of continuous professional education.

To ensure content validity of the developed diagnostic toolkit, structured and semi-structured interviews with experts (specialists in social work) aimed at identifying the most important characteristics of the phenomenon under study were conducted. At this stage, our goal was to test the developed toolkit, but not to obtain results that could be generalized to the general population.

To diagnose respondents according to the value criterion, we have developed the questionnaire "Determination of future social workers' motivational-value readiness for home-nursing work with the elderly", which includes 5 blocks characterizing moral, sociopsychological, organizational, managerial and informational-cognitive aspects of future social workers' readiness for home-nursing work with elderly people.

To determine readiness level according to the informational criterion, expert evaluations made by teachers and practitioners have been used. In order to achieve greater objectivity of this method, each result was evaluated by independent experts, and the results obtained were averaged by calculating arithmetic mean value.

Future social workers will reach the maximum success in their professional activity when they gain the appropriate professional skills, techniques, methods and 
ways of their realization and development. Knowledge and skills were diagnosed by using "Diagnostics of professional competence level" questionnaire adapted to new conditions on the basis of O. Karpenko's questionnaire [3, p. 354]. With the help of this questionnaire, we determined levels of future social workers' readiness for home- nursing work with the elderly according to indicators of the informational and competence criteria.

Based on a detailed analysis of the state of future social workers' readiness for home-nursing work with elderly people, average value results are graphically presented in Fig. 1.

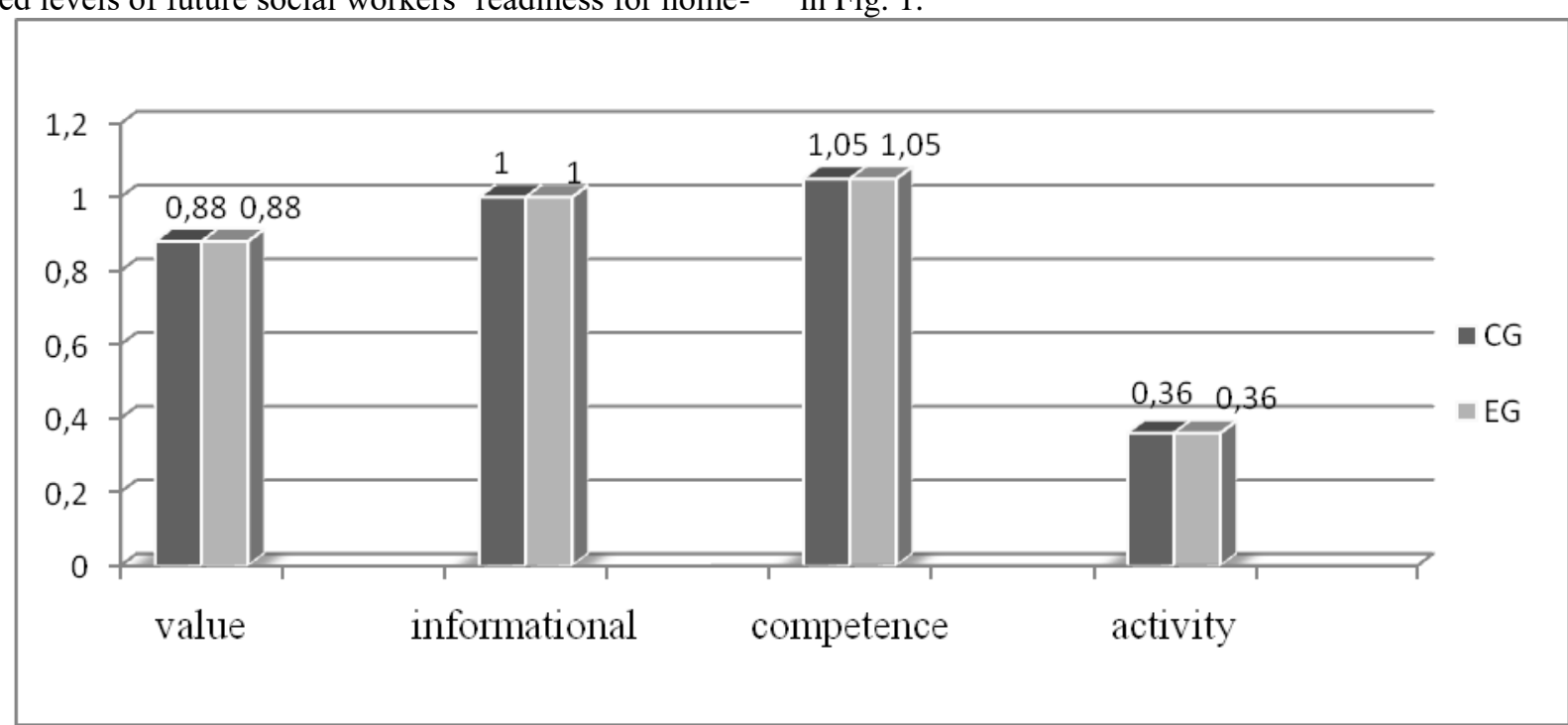

Fig. 1. Evaluation of future social workers' readiness for home-nursing work with elderly people according to four criteria at the diagnostic stage (average values)

Real conditions of future social workers' readiness for home-nursing work with the elderly according to three levels of the value, informational, competence and activi- ty criteria at the diagnostic stage have been analyzed and graphically reflected in Table 2.

Summarizing the results according to the levels of future social workers'

Table 2. readiness for home-nursing work with elderly people. Diagnostic stage

\begin{tabular}{|c|c|c|c|c|c|c|c|c|c|c|c|c|c|}
\hline \multirow{3}{*}{ Criteria } & \multirow{3}{*}{ Levels } & \multicolumn{4}{|c|}{ Low Level } & \multicolumn{4}{|c|}{ Medium Level } & \multicolumn{4}{|c|}{ High Level } \\
\hline & & \multicolumn{2}{|c|}{$\begin{array}{c}\text { CG } \\
210 \text { p. }\end{array}$} & \multicolumn{2}{|c|}{$\begin{array}{c}\text { EG } \\
200 \text { p. }\end{array}$} & \multicolumn{2}{|c|}{$\begin{array}{c}\text { CG } \\
210 \mathrm{p} .\end{array}$} & \multicolumn{2}{|c|}{$\begin{array}{c}\text { EG } \\
200 \text { p. }\end{array}$} & \multicolumn{2}{|c|}{$\begin{array}{c}\text { CG } \\
210 \text { p. }\end{array}$} & \multicolumn{2}{|c|}{$\begin{array}{c}\text { EG } \\
200 \mathrm{p} .\end{array}$} \\
\hline & & $\%$ & $\begin{array}{l}\text { q- } \\
\text { ty }\end{array}$ & $\%$ & $\begin{array}{l}\text { q- } \\
\text { ty }\end{array}$ & $\%$ & $\begin{array}{l}\text { q- } \\
\text { ty }\end{array}$ & $\%$ & $\begin{array}{l}\text { q- } \\
\text { ty }\end{array}$ & $\%$ & $\begin{array}{l}\text { q- } \\
\text { ty }\end{array}$ & $\%$ & $\begin{array}{l}\text { q- } \\
\text { ty }\end{array}$ \\
\hline Value & & 24,3 & 51 & 24,5 & 49 & 65,7 & 138 & 65,5 & 131 & 10,0 & 21 & 10,0 & 20 \\
\hline Informational & & 18,9 & 40 & 19,8 & 38 & 51,6 & 108 & 51,1 & 104 & 29,5 & 62 & 29,1 & 58 \\
\hline Competence & & 25,5 & 54 & 25,5 & 51 & 49,0 & 102 & 48,5 & 97 & 25,5 & 54 & 26,0 & 52 \\
\hline Activity & & 36,3 & 76 & 36,5 & 73 & 63,7 & 133 & 63,5 & 127 & - & - & - & - \\
\hline General stati & l meaning & 26,3 & 56 & 26,5 & 53 & $\mathbf{5 7 , 5}$ & 120 & 57,0 & 114 & 16,2 & 34 & 16,5 & 33 \\
\hline Total & & 0,2 & & & & 0,5 & & & & 0,3 & & & \\
\hline
\end{tabular}




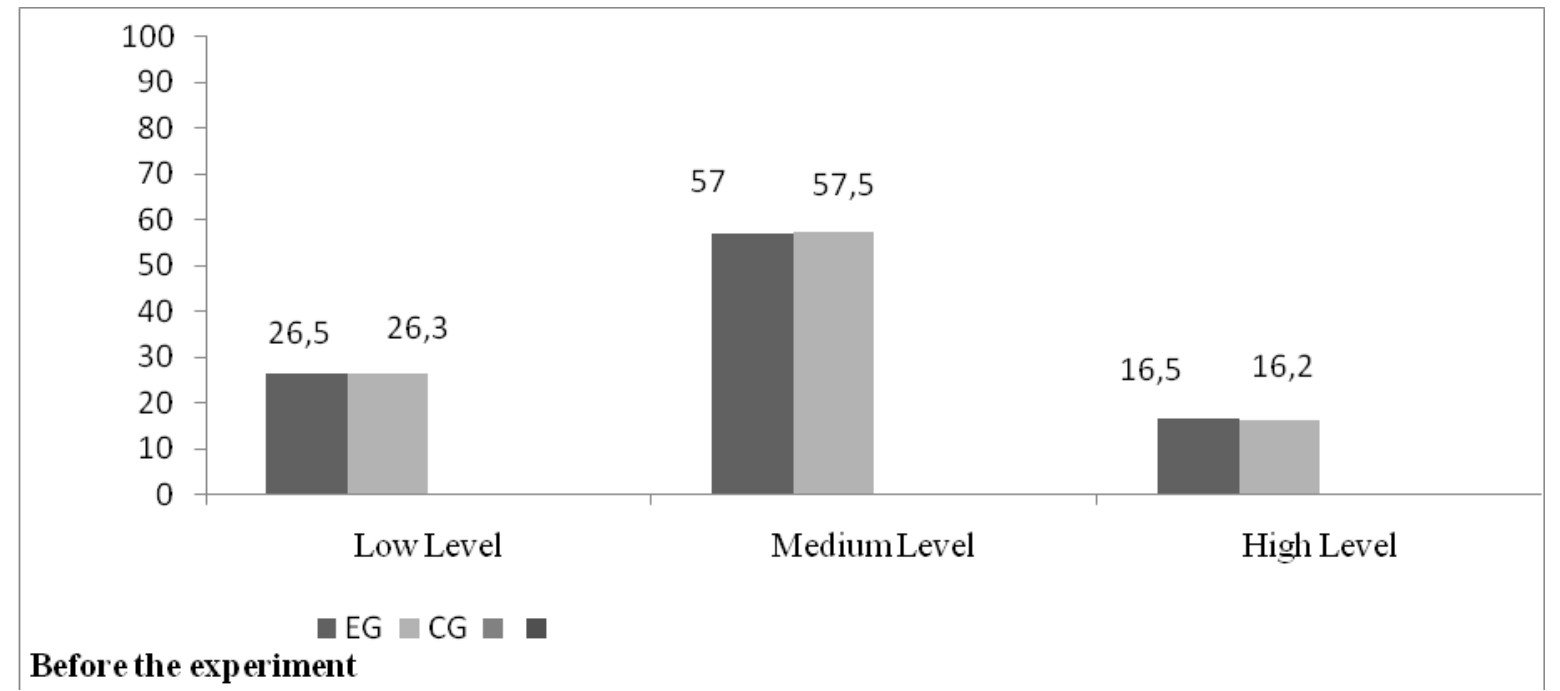

Fig. 2. Indicators of future social workers' readiness for home-nursing work with elderly people (diagnostic experiment)

Analyzing the summarized data of diagnostic experiment according to three levels of four readiness criteria, we can state the following:

- the low readiness level, corresponding to the initial one, is $26.5 \%$ in the experimental group (EG) and $26.3 \%$ in the control group (CG), the difference is insignificant only $0.2 \%$;

- the medium level of students' readiness for homenursing work with the elderly is observed at the level of $57.0 \%$ in EG, and at the level of $57.5 \%$ in CG, the difference is also insignificant $-0.5 \%$;

- the high level indicator that corresponds to the constructive readiness, has a slight difference both in the experimental and control groups $-0.3 \%$ (EG $-16.5 \%$, $\mathrm{CG}-16.2 \%$ ).

The obtained data prove that the real state of future social workers' readiness for home-nursing work with the elderly is at low and medium levels $(83.5 \%$ - in EG, $83.8 \%$ - in CG).

This situation has led to the search for ways and mechanisms to increase the level of future social workers' readiness for home-nursing work with the elderly. Due to this purpose, we have identified scientific and pedagogical factors for its implementation and developed didactic and methodological support for the process of future social workers' readiness for home-nursing work with elderly people formation.

At the summative stage of our pedagogical experiment, the following tasks have been solved:

1) establishing the fact that shortcomings identified in diagnostic experiment can be partially or completely eliminated in the process of the formation of future social workers' readiness for home-nursing work with elderly people;
2) evaluating knowledge and skills acquired during the study of educational course "Socio-medical patronage", author's module "Technologies of social work with the elderly", creation of a volunteer group "Towards people", organized experimental studio "Fundamentals of home-nursing work with elderly people" and development of methodological recommendations for students' practical work under the influence of active pedagogical factor;

3 ) studying the dynamics of the development of future social workers' readiness for home-nursing work with elderly people;

4) determining the statistical significance of the results obtained.

After the formative stage of the experiment there is a tendency of the percentage increase of the middle and high levels due to the absence of the low level. According to this criterion, there was no high level formed in the control groups at the summative stage, and there are slight changes in the direction of growth at the formative stage (from $0 \%$ to $27.0 \%$ (57 persons).

The noticeable dynamics of readiness levels can be explained by the fact that during their practice students realized the need for its narrow orientation, manifested in the effective development of skills and abilities.

Therefore, closing our discussion of the results according to four proposed components, we have calculated average statistical meanings for three levels of readiness, and after a thorough analysis of indicators according to the four criteria, we can summarize the results of average values and display them graphically (Fig. 3).

The analysis of data obtained at the formative stage shows a significant increase in future social workers' readiness for home-nursing work with the elderly according to all 4 criteria in the experimental group (Table 3 ). 


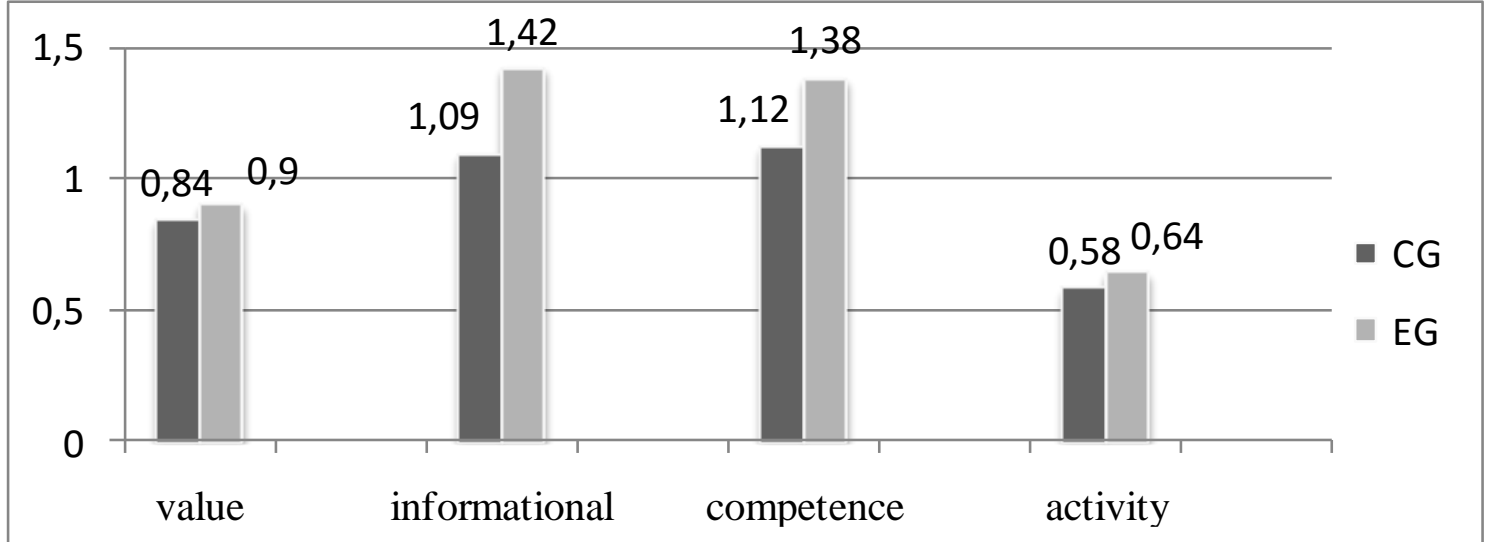

Fig. 3. Dynamics of changes in levels of future social workers' readiness for home-nursing work with elder people according to 4 criteria in the experimental and control groups (formation experiment)

Table 3.

Summarizing the results of future social workers' readiness for home-nursing work with elderly people according to three levels at the formative stage

\begin{tabular}{|c|c|c|c|c|c|c|c|c|c|c|c|c|c|}
\hline \multirow[t]{3}{*}{ Criteria } & \multirow{3}{*}{$\begin{array}{l}\text { Levels } \\
\text { lubso- } \\
\text { and \% }\end{array}$} & \multicolumn{4}{|c|}{ Low Level } & \multicolumn{4}{|c|}{ Medium Level } & \multicolumn{4}{|c|}{ High Level } \\
\hline & & \multicolumn{2}{|c|}{$\begin{array}{l}\text { CG } \\
210 \text { p. }\end{array}$} & \multicolumn{2}{|c|}{$\begin{array}{l}\text { EG } \\
200 \text { p. }\end{array}$} & \multicolumn{2}{|c|}{$\begin{array}{l}\text { CG } \\
210 \text { p. }\end{array}$} & \multicolumn{2}{|c|}{$\begin{array}{l}\text { EG } \\
200 \text { p. }\end{array}$} & \multicolumn{2}{|c|}{$\begin{array}{l}\text { CG } \\
210 \text { p. }\end{array}$} & \multicolumn{2}{|c|}{$\begin{array}{l}\text { EG } \\
200 \text { p. }\end{array}$} \\
\hline & & $\%$ & $\begin{array}{l}\text { q- } \\
\text { ty }\end{array}$ & $\%$ & $\begin{array}{l}\text { q- } \\
\text { ty }\end{array}$ & $\%$ & q-ty & $\%$ & q-ty & $\%$ & $\begin{array}{l}\text { q- } \\
\text { ty }\end{array}$ & $\%$ & q-ty \\
\hline \multicolumn{2}{|l|}{ Value } & 16,5 & 35 & 11,0 & 22 & 73,2 & 153 & 70,0 & 140 & 10,3 & 22 & 19,0 & 38 \\
\hline \multicolumn{2}{|l|}{ Informational } & 16,9 & 35 & 10,5 & 21 & 53,3 & 112 & 27,0 & 54 & 29,8 & 63 & 62,5 & 125 \\
\hline \multicolumn{2}{|l|}{ Competence } & 24,1 & 50 & 8,5 & 17 & 42,3 & 89 & 38,0 & 76 & 33,6 & 71 & 53,5 & 107 \\
\hline \multicolumn{2}{|l|}{ Activity } & 17,6 & 37 & - & - & 55,4 & 116 & 51,0 & 102 & 27,0 & 57 & 49,0 & 98 \\
\hline \multicolumn{2}{|c|}{ Average statistical meaning } & 18,8 & 39 & 7,5 & 15 & 56,1 & 118 & 46,5 & 93 & 25,1 & 53 & 46,0 & 92 \\
\hline \multicolumn{2}{|l|}{ Total } & \multicolumn{4}{|c|}{$-11,3$} & \multicolumn{4}{|l|}{$-9,5$} & \multicolumn{4}{|c|}{$+20,9$} \\
\hline
\end{tabular}

Thus, the dynamics of changes in the high level of future social workers' readiness for home-nursing work with elderly people has been revealed in the experimental group.

\section{Conclusions}

Consequently, at the formative stage of the experiment, the high level in the experimental group increased by $29.5 \%$, and in the control group - only by $8.9 \%$.

Based on the data obtained during our researchexperimental work, some general conclusions can be made. At the diagnostic stage there were only $16.5 \%$ of students (33 persons) who had the high (constructive) readiness level in the experimental group, but at the end of the formative stage of the experiment there were $46.0 \%$ (92 persons) (the difference is $29.5 \%$ ). This means that the students passed to the high (constructive) level of readiness for home-nursing work with the elderly, while the number of students in the experimental group who had the low (initial) readiness level decreased significantly - compared to the diagnostic stage by

\section{REFERENCES}

1. Bogomolets, A. A. (1940). Prodleniye zhizni [Life prolongation]. Kiev: AN USSR [in Russian].

2. Frolkis, V. V. (1981). Stareniye. Neirogumoralnyye mekhanizmy [Aging. Neurohumoral mechanisms]. Kiev: Nauk. Dumka [in Russian].
$19.0 \%$ (from $26.5 \%$ (53 persons) to $7.5 \%$ (15 persons), and only by $7.5 \%$ (from $26.3 \%$ (56 persons) to $18.8 \%$ (39 persons) in the control group.

It should be mentioned that analyzing the data of evaluation of future social workers' readiness for homenursing work with elderly people there are advantages of readiness indicators formation according to four criteria, which consist in person-oriented training, developing a practical orientation towards the implementation of homenursing work with the elderly. The research does not cover all aspects of solving the problems of students' training for home-nursing work with elderly people.

Further research studies will be focused on future social workers' professional competence formation; development of new models of students' training for the implementation of home-nursing work with the elderly; activation of students' professionally-oriented interest toward home-nursing work with elderly people.

3. Karpenko, O. H. (2007). Profesiyna pidhotovka sotsialnyh pratsivnykiv $v$ umovah universytetskoyi osvity: naukovo-metodychnyi ta orhanizatsiyno-tekhnolohichnyi aspekty: monographiia [Social workers' professional training under conditions of university education: scien- 
tific-methodical and organizational-technological aspects: monograph]. Drohobych: Kolo [in Ukrainian].

4. Uznadze, D. N. (1997). Teoriya ustanovki [Set theory]. Voronezh: NPO "MODEK"; Moscow: Institut prakticheckoy psikhologii [in Russian].

5. Dyachenko, M. I. \& Kandybovich, L. A. (1976). Pedagogicheskiye problemy gotovnosti $k$ deyatelnost [Pedagogical problems of activity readiness]. Minsk: Izdvo BGU [in Russian].

6. Slastyonin, V. A. (1993). Sotsialnyi pedagog i sotsialnyi rabotnik: lichnost i professiya [Social teacher and social worker: personality and profession]. Teoriya i praktika sotsialnoy raboty. Otechestvennyi $i$ zarubezhnyi opyt - Theory and Practice of Social Work. Domestic and Foreign experience, (pp. 265-274) [in Russian].

7. Bezpalko, O. V. (2005). Sotsialna robota v hromadi: navch. posib. [Social work in the community: tutorial]. Kyiv: Tsentr navch. lit-ry [in Ukrainian].

8. Kapska, A. I. (2011). Sotsialna robota: navch. posib. [Social work: tutorial]. Kyiv: Vydavnychyi dim "Slovo" [in Ukrainian].

9. Karpenko, O. H. (2008). Profesiyna pidhotovka sotsialnyh pratsivnykiv $\mathrm{v}$ umovah universytetskoyi osvity [Social workers' professional training under conditions of university education]. Doctor's thesis. Kyiv [in Ukrainian].

10. Kozubovska, I. V. \& Dosin, A. R. Vykorystannya dosvidu Velykoyi Brytaniyi u praktychniy pidhotovtsi fahivtsiv sotsialnoyi roboty v Ukrayini [The use of Great Britain experience in the practical training of social work specialists in Ukraine]. Pedahohichna nauka: istoriia, teoriia, praktyka, tendentsiyi rozvytku - Pedagogical Science: History, Theory, Practice, Development Tendencies. Retrieved from: http://intellectinvest.org.ua/pedagog_editions_emagazine

_pedagogical_science_arhiv_pn_n1_2008_st_29/>

[in Ukrainian].

11. Mishchyk, L. I. (1997). Teoretyko-metodychni osnovy profesiynoyi pidhotovky sotsialnoho pedahoha $\mathrm{u}$ zakladakh vyshchoyi osvity [Theoretical and methodological foundations of social teachers' professional training

\section{ЛІТЕРАТУРА}

1. Богомолец А. А. Продление жизни / А. А. Богомолец. - К.: АН УССР, 1940. - 143 с.

2. Фролькис В. В. Старение. Нейрогуморальные механизмы / В. В. Фролькис. - К.: Наук.думка, 1981. $320 \mathrm{c}$.

3. Карпенко О. Г. Професійна підготовка соціальних працівників в умовах університетської освіти: науково-методичний та організаційнотехнологічний аспекти : монографія / О. Г. Карпенко за ред. С. Я. Харченко. - Дрогобич: Коло, 2007. $374 \mathrm{c.}$

4. Узнадзе Д. Н. Теория установки / Д. Н. Узнадзе. - Воронеж : НПО «МОДЭК» ; Москва : Институт практической психологии, 1997. - 448 с.

5. Дьяченко М. И. Педагогические проблемы готовности к деятельности / М. И. Дьяченко, Л. А. Кандыбович. - Минск : Из-во БГУ, 1976. - 175 с.

6. Сластенин В. А. Социальный педагог и социальный работник: личность и профессия В. А. Сластенин // Теория и практика социальной in higher education institutions]. Doctor's thesis. Zaporizhzhya [in Ukrainian].

12. Poltavets, V. (2000). Sotsialna robota $v$ Ukrayini: pershi kroky [Social Work in Ukraine: The First Steps]. Kyiv: Vyd. dim "KM Akademiia" [in Ukrainian].

13. Semyhina, T. V. (2005). Porivnyalna sotsialna polityka: navch posib. [Comparative social policy: tutorial]. Kyiv: MAUP [in Ukrainian].

14. Kharchenko, S. Ya. (1999). Didakticheskiye osnovy podgotovki studentov $k$ sotsialno-pedagogicheskoy deyatelnosti [Didactic bases of students' training for social-pedagogical activity]. Luhansk: Alma-Mater [in Russian].

15. Kolenichenko, T. I. (2010). Osoblyvosti adaptatsiyi lyudey pokhyloho viku do umov novoho sotsialnoho seredovyshcha [Adaptation peculiarities of the elderly people to the conditions of the new social environment]. Candidate's thesis. Kyiv [in Ukrainin].

16. Matskevych, Yu. R. (2003). Pidhotovka sotsialnykh pedahohiv do roboty $\mathrm{z}$ lyudmy pokhyloho viku [Professional training of social pedagogues for the work with elderly people]. Candidate's thesis. Luhansk [in Ukrainian].

17. Topol, O. (2012). Starist u konteksti sotsialnoyi roboty: monohrafiia [Old age in the context of social work: monograph]. Kyiv: Vyd-vo NPU imeni M. P. Drahomanova [in Ukrainian].

18. Tiuptia, L. T. (2008). Sotsialna robota: teoriya $i$ praktyka : navch. posib. [Social work; theory and practice: tutorial]. Kyiv: Znannia [in Ukrainian].

19. Averbukh, Ye. S. (1969). Rasstroystva psikhicheskoy deyatelnosti $v$ pozdnem vozraste: Psikhiatricheskiy aspekt gerontologii i geriatrii [Disorders of mental activity in later age: Psychiatric aspect of gerontology and geriatrics]. Leningrad: Meditsina, Leningr. otd-ye [in Russian].

20. Holubenko, T.O. (2015). Formuvannya hotovnosti maybutnikh sotsialnykh pratsivnykiv do patronazhnoyi roboty $z$ lyudmy pokhyloho viku [Formation of future social workers' readiness for home-nursing work with elderly people]. Kyiv [in Ukrainian].

работы: Отечественный и зарубежный опыт. - М.; Тула, 1993. - С. 265-274.

7. Безпалько О. В. Соціальна робота в громаді: навч. посіб. / О. В. Безпалько. - К. : Центр навч. л-ри, 2005. - $21 \mathrm{c}$

8. Капська А. Й. Соціальна робота : навч. посіб. / А. Й. Капська. - К.: Видавничий Дім «Слово», 2011. $-400 \mathrm{c}$.

9. Карпенко О. Г. Професійна підготовка майбутніх соціальних працівників в умовах університетської освіти : дис. ...д-ра пед. наук : 13.00.04 / Олена Георгіївна Карпенко. - К., 2008. - 546 с.

10. Козубовська I. В. Використання досвіду Великої Британії у практичній підготовці фахівців соціальної роботи в Україні / I. В. Козубовська, А. Р. Досін // Педагогічна наука: історія, теорія, практика, тенденції розвитку [Електронний ресурс]. Режим доступу: 26.06.2013<http://intellectinvest.org.ua/pedagog_editions_emagazine_ pedagogical_science_arhiv_pn_n1_2008_st_29/>. 
11. Міщик Л.І. Теоретико-методичні основи професійної підготовки соціального педагога у закладах вищої освіти: дис. ... д-ра пед. наук: 13.00 .05 / Людмила Іванівна Міщик. - Запоріжжя, 1997. - 359 с.

12. Полтавець В. Соціальна робота в Україні: перші кроки / В. Полтавець. - К.: Вид. дім «КМ Академія», 2000. - 233 с.

13. Семигіна Т. В. Порівняльна соціальна політика : навч. посіб. / Т. В. Семигіна. - К.: МАУП, 2005. $276 \mathrm{c}$.

14. Харченко С. Я. Дидактические основы подготовки студентов к социально-педагогической деятельности / С. Я. Харченко. - Луганск: Альма-матер, 1999. $-138 \mathrm{c}$.

15. Коленіченко Т. І. Особливості адаптації людей похилого віку до умов нового соціального середовища : дис. ... канд. пед. наук : 13.00 .05 / Тетяна Іванівна Коленіченко. - К., 2010. - 220 с.

16. Мацкевич Ю. Р. Підготовка соціальних педа- гогів до роботи з людьми похилого віку : дис. ... канд. пед. наук : 13.00.05 / Юліана Рафаілівна Мацкевич. Луганськ, 2003. - 220 с.

17. Тополь О. Старість у контексті соціальної роботи: монографія / Ольга Тополь. - К.: Вид-во НПУ імені М.П. Драгоманова, 2012. - 308 с.

18. Тюптя Л. Т. Соціальна робота: теорія і практика : навч. посіб. / Л. Т. Тюптя, І. Б. Іванова. - К. : Знання, 2008. - 574 с.

19. Авербух. Е. С. Расстройства психической деятельности в позднем возрасте: Психиатрический аспект геронтологии и гериатрии / Е. С. Авербух. - Л.: Медицина, Ленингр. отд-е, 1969. - 285 с.

20. Голубенко Т. О. Формування готовності майбутніх соціальних працівників до патронажної роботи 3 людьми похилого віку: дис. ... канд. пед. наук: 13.00.05 / Тетяна Олександрівна Голубенко; НПУ імені М.П. Драгоманова. - Київ, 2015. - 227 с.

Тетяна Олександрівна Голубенко, кандидат педагогічних наук, дочент кафедри теорї та технології соиіальної роботи, Національний педагогічний університет імені М. П. Драгоманова, вул. Пирогова 9, м. Київ, Украӥна

\section{НАУКОВО-ПЕДАГОГІЧНІ ФАКТОРИ ПРОЦЕСУ ФОРМУВАННЯ ГОТОВНОСТІ МАЙБУТНІХ ФАХІВЦІВ СОЦАЛЬНОЇ СФЕРИ ДО ПАТРОНАЖНОӤ РОБОТИ З ЛЮДЬМИ ПОХИЛОГО ВІКУ}

У статті проаналізовано результати констатувального та експериментального дослідження науково-педагогічних факторів процесу формування готовності майбутніх соціальних працівників до патронажної роботи з людьми похилого віку. Проведено ретельний пошук для оптимізації навчально-виховного процесу таких варіантів прийняття найкращого науково-методичного рішення, який б найбільш продуктивно сприяв формуванню готовності майбутніх соціальних працівників до патронажної роботи з людьми похилого віку на фундаменті оволодіння студентами основними соціальними, педагогічними знаннями та вміннями. У дослідженні науково-педагогічних факторів процесу формування готовності майбутніх соціальних працівників до патронажної роботи з людьми похилого віку представлена сукупністю чотирьох компонентів: мотиваційно-ціннісний, когнітивно-орієнтаційний, змістово-професійний, практично-діяльнісний. Відповідно до них було сформульовано чотири критерії: ціннісний, інформаційний, компетентнісний та діяльнісний. Розроблено характеристику рівнів готовності майбутніх соціальних працівників до патронажної роботи з людьми похилого віку шляхом встановлення конкретних ознак, які характеризують прояв їх основних критеріїв. Низький рівень готовності виступає як початковий. Середній рівень (репродуктивний) характеризує емоційно-ціннісне ставлення студентів до проблем професійного самовдосконалення. Високий рівень (конструктивний) характеризується повною реалізацією у студентів мотиваційно-ціннісної, когнітивно-орієнтаційної, змістово-операційної та практично-діяльнісної готовності до патронажної роботи з людьми похилого віку. Визначено готовність до патронажної роботи 3 людьми похилого віку як соціально-психологічний та професійний прояв студентами зв'язку професійної спрямованості з іншими важливими властивостями особистості (світоглядом, життєвими настановами і духовними цінностями, морально-вольовою та емоційною сферами), що передбачає сформованість моральних цінностей, інтелектуальних якостей, знань, умінь і навичок до здійснення патронажної роботи з людьми похилого віку. Проаналізовано стан готовності майбутніх соціальних працівників до патронажної роботи з людьми похилого віку за трьома рівнями ціннісного, інформаційного, компетентнісного і діяльнісного критеріїв на констатувальному та формувальному етапах дослідження. Доведено, що в ході аналізу даних щодо оцінки готовності майбутніх соціальних працівників до патронажної роботи 3 людьми похилого віку є переваги сформованості показників готовності за чотирма критеріями, які полягають у особистісно-орієнтованій підготовці, формуванні практичного спрямування в процесі формування готовності майбутніх соціальних працівників до зазначеного виду професійної діяльності.

Ключові слова: готовність, формування готовності, констатувальний експеримент, формувальний експеримент патронажна робота, людина похилого віку, майбутній соціальний працівник.

Submitted on April, 12, 2017 